\title{
Comments
}

\section{PREVENTIVE INTELLIGENCE SYSTEMS AND THE COURTS}

The following Comment discusses the burgeoning of preventative intelligence systems-sophisticated data banks replete with dossiers cataloguing in detail the political lives of active individuals and groups -and what the role of the court should be when faced with a challenge to these police practices.

The police, security and military intelligence agencies of the federal government are quietly compiling a mass of computerized and microfilmed files here on hundreds of thousands of law abiding yet suspect Americans.

With the justification that a revolutionary age of assassination, violent political dissent and civil disorder requires it, the Government is building an array of instantly retrievable information on "persons of interest."

The phrase is an agent's term for those citizens, many with no criminal records, whom the Government wants to keep track of in an effort to avert subversion, rioting and violence or harm to the nation's leaders. ${ }^{1}$

The political and social crises of the past decade have unnerved and frightened many Americans. Assassinations, ghetto unrest, vigorous political dissent, demonstrations which on occasion degenerate into violence, sporadic terrorism and bounbings have produced an uneasiness and a divisive breakdown of consensus unparalleled in this century. Increasing proportions of the population crave tranquility-and have expressed a willingness to pay for that stability with the cold hard currency of repression. ${ }^{2}$

The entrenchment of a political police is one possible grim result of an intemperate push for stability. There is increased acceptance of

1. Franklin, Federal Computers Amass Files on Suspect Citizens, N.Y. Times, June 28, 1970, at 1, col. 3 .

2. CBS recently conducted a poll of 1,136 persons the results of which were reported in TIME, Apr. 27, 1970, at 19.76 percent of those polled answered 'no' to the question, "as long as there appears to be no clear danger of violence, do you think any group, no matter how extreme, should be allowed to organize protests versus the Government?" 54 percent of those polled answered 'no' to the question, "do you think everyone should have the right to criticize the Government, even if the criticism is damaging to our national interests?" 
the notion that all forms of vigorous and vocal political dissent are tainted, unpatriotic, and decidedly un-American: our society increasingly views political protests as inimical to internal security and fails to detect the differences between political behavior employing legitimate, established, and protected means of advocacy from political activity using extra-legal means of expression and terror. Federal law enforcement agencies-and groups such as the Army Intelligence Command which presume to function as federal law enforcement agencies ${ }^{3}$-fashion swift and perhaps ill-conceived responses to these real and imagined sources of instability. Their attitudes and actions influence the posture of state and local police; ${ }^{4}$ and these attitudes manifest themselves as heavy-handed and unrefined attempts to characterize in a wholesale manner the entire spectrum of legal and indeterminately legal political activity as suspect and uniformly dangerous. ${ }^{5}$ One disturbing result of such attitudes is the burgeoning of "preventative imtelligence systems" - sophisticated data banks replete with dossiers cataloguing in minute detail the lives and activities of politically active imdividuals and groups.

This Comment will: First, briefly examine the reasons for the constantly expanding use of preventative intelligence systems and will indicate how sucl systems are being used today; second, discuss legal

3. See text accompanying notes 23-30 infra.

4. See text accompanying notes 31-58 infra.

5. The FBI evidently subscribes to a conspiratorial theory in which the machinations of the Students for a Democratic Society and the Black Panthers are virtually singlehandedly responsible for unrest and discord in the United States.

The New Left movement continued to pose a serious threat to the Nation's internal security. During the last year, this extremist minority group, located primarily on college campuses, was imvolved in considerable violence, sabotage and revolutionary activity. . . .

The militant core of New Left extremism is the Students for a Democratic Society (SDS). . . . The SDS openly espouses the overthrow of our institutions of free society (called the "Establishment") through violent revolutionary action. Never before in American history has there been such a strong revolutionary Marxist movement of young people so eager to tear down established authority.

SDS has an estimated 250 chapters and claims some 40,000 members, but in actuality it has been able to influence the thinking and actions of many thousands of students. The SDS bitterly opposes the war in Vietnam, the draft, American foreign policy, "the military-imdustrial complex," ROTC, private imdustry, labor unions, and our educational system. . . .

A problem closely related to New Left extremism has been Black extremism, especially centering around the Black Panther Party. . . . Black extremists detest constitutional government, encourage disrespect for the law, and advocate violence.

....

The Black Panthers experienced a rapid growth when Leroy Eldridge Cleaver became a spokesman and its Minister of Information. ... The Panther political philosophy is based on the writings of Mao Tse-Tung. Recently the Panthers have attempted to spread their doctrine of hate and revolution to college and high school students.

1969 FBI ANNUAL REPORT 21, 22. 
problems and theories relating to the role of a court in adjudicating the merits of such systems when they are challenged in a lawsuit; and, third, suggest further avenues of inquiry concerning the legality or illegality of preventative intelligence systems.

\section{I}

\section{CAUSES AND CURRENT USE OF PREVENTATIVE INTELLIGENCE SYSTEMS}

\section{A. The Kennedy Assassination and its Aftermath}

The assassination of President Kennedy occasioned intensive reexamination of methods devised for the protection of the hife of the President. The federal agencies directly and indirectly responsible $e^{0}-$ the FBI, the Secret Service, and the CIA-embarked on a complete overhaul of their research activities and significantly increased their use of and dependence upon preventative intelligence. And the Warren Commission endorsed this wider use of dossiers. ${ }^{7}$ Indeed, the Commission apparently regarded the use of preventative imtelhigence as necessary for minimizing intolerable threats to the constitutional processes of government. ${ }^{8}$

In the Commission's view, the failure of the FBI to notify the Secret Service of the substantial information it had accumulated on Lee Harvey Oswald prior to President Kennedy's trip to Dallas contributed to the inability of the Secret Service to adequately protect the President's life. ${ }^{\theta}$ The Commission concluded that the FBI and the Secret Service construed their responsibilities too narrowly. ${ }^{10}$ The FBI met this criticism squarely: it broadened the scope of its protective research files to include not only those individuals communicating actual threats on the President's life but also

[s]ubversives, ultrarightists, racists and fascists (a) possessing emotional instability or irrational behavior, (b) who have made threats of bodily harm against officials or employees of Federal, state or local government or officials of a foreign government, (c) who express or have expressed strong or violent anti-U.S. sentiments or who have

6. See Report of the Warren Commission on the Assassination of PresiDENT KENNEDY 433-34 (N.Y. Times ed. 1964) [hereinafter cited as WARREN COMMISSION REPORT].

7. Id. at $437-42$.

8. Id.

9. [T]he Secret Service had no knowledge whatever of Oswald, his background, or his employment at the Book Depository, and Robert I. Bouck, who was in charge of the Protective Research Section of the Secret Service, believed that the accumulation of facts known to the FBI should have constiId. at 434. tuted a sufficient basis to warn the Secret Service of the Oswald risk.

10. Id. 
been involved in bombing or boinb-making or whose past conduct indicates tendencies toward violence, and (d) whose prior acts or statements depict propensity for violence and hatred against organized government. ${ }^{11}$

The Secret Service broadened the scope of its concern to include individuals and groups demonstrating an "imterest in the President or "other high government officials in the nature. of a complaint coupled with an expressed or implied determination to use a means, other than legal or peaceful, to satisfy any grievance, real or imagined." "'12 Included within this class are "activists, 'malcontents,' persistent seekers of redress, and those who would 'embarrass' the President or other government leaders."13

The Warren Commission concluded that the Secret Service's liaison with other intelligence agencies was too casual: ${ }^{14}$ prior to the assassination, the Service was merely the passive recipient of information from other intelligence groups, particularly the FBI. The Commission recommended that the Secret Service enter into written agreements with federal, state, and local agencies which might be a source of information and the Secret Service has apparently complied. ${ }^{15}$

\section{B. Expanding Use of Preventative Intelligence Systems}

Threats of lesser magnitude than presidential assassination have prompted the use of preventative intelligence in unprecedented proportions. In response to the ghetto disturbances and political demonstrations of recent years, federal, state, and local police ${ }^{16}$ have perceived a

\section{Id. at 438 .}

12. Id. at 439.

13. Franklin, supra note 1 , at 42 , col. 3 .

14. The Secret Service's liaison with the agencies that supply information to it has been too casual. Since the assassination, the Service has recognized that these relationships must be far more formal, and each agency given clear understanding of the assistance which the Secret Service expects.

Once the Secret Service has formulated its new standards for collection of information, it should enter into written agreements with each Federal agency and the leading State and local agencies that might be a source of such information. Such agrcements should describe in detail the information which is sought, the manner in which it will be provided to the Secret Service, and the respective responsibilities for any further investigation that may be required.

This is especially necessary with regard to the FBI and the CIA, which carry the major responsibility for supplying information arising from organized groups, within their special jurisdicton.

WARREN COMMISSTON REPORT 440.

15. See Franklin, supra note 1, at 1, col. 3. See also WARREN COMMISSION REPORT 440.

16. Campus administrators also have begun to compile dossiers. In 1962, for example, the Yale News reported that one of the University's Deans, a former. FBI agent, maintained dossiers containing records on faculty and undergraduates "that might go that way." He reportedly compiled information on groups and individuals he con- 
need for elaborate infornation gathering systems and files. The number of such files has reportedly "grown explosively over the last two decades."17

At the federal level, for example, the Justice Department's civil disturbance group makes extensive use of a data bank which "produces a weekly printout of national tension points on racial, class and political issues and the individuals and groups involved in them. Intelligence on peace rallies, welfare protests and the like provide the 'data base' agamst which the computer measures the mood of the nation and the militancy of its citizens. Judgments are made; subjects are listed as 'radical' or 'inoderate.' "18

State and local police emulate federal agents. One writer ${ }^{10}$ recently publicized the activities of "Bossi"-the Bureau of Special Services and Investigations of the New York City Police Department. Bossi maintains "literally thousands of dossiers on residents of New York who might be considered radicals or 'far-out'-including, according to one report, a file on Mayor Lindsay."20 Militancy, according to an informed police source, is not a prerequisite to a place in the files. ${ }^{21}$ "[S]omeone like [Daniel Patrick] Moynihan is considered pretty far out by Bossi and a lot of people like him are in the files." 22

Christopher Pyle, reportimg in the Washington Monthly, suggests that the Army is not to be outdone in the business of keeping track of political activists. ${ }^{23}$ The Army maintains "files on the membership, ideology, programs and practices of virtually every activist political group in the country." 24 Not limiting dossiers to violence-prone or-

sidered suspicious or liable to be engaged in subversion and gave access to his files to security officers from government agencies. See F. COoK, THE FBI NoBODY KNows 379 (1964). In the same vein, the 108th Military Intelligence Group in Manhattan "quietly persuaded an employee of [Columbia University's] Registrar's Office to disclose information from closed files on the sly." Pyle, The Army Watches Civilian Politics, WASHINGTON MONTHLY, Jan. 1970, at 5.

17. Stern, The Loyalty Program: A Case for Termination, Washington MonthLY, Nov. 1969, at 37. "In addition to those of the FBI and the CIA, Columbia Law School professor Alan F. Westin reports that the Department of Defense has 14 million life histories in its security files, the Civil Service Coinmission eight million.'" Id.

18. Franklin, supra note 1 , at 42 , col. 3 .

19. Wicker, The Undeclared Witch-Hunt, HARPER's, Nov. 1969, at 109.

20. Id.

21. Burnham, Police Unit Here Checks Radicals, N.Y. Times, Aug. 8, 1969, at 30C, col. 6 .

22. Id.

23. Pyle, supra note 16 , at 4 .

24. Id. at 5. See also Kondraacke, The Army Still Spies on Civilians, S.F. Sunday Examiner \& Chronicle, Mar. 15, 1970, \$ A, at 1, col. 6; at 20, col. 1, where, in discussing the political intelligence activities of the 116th Military Intelligence Group, the author reports that:

Information [is] collected by the 116th [and] transferred to a file of 5 by 7 
ganizations, ${ }^{25}$ the Army has records on such groups as the American Civil Liberties Union, the National Association for the Advancement of Colored People, and the Clergy and Laymen Against the War in Vietnam. ${ }^{26}$ According to Pyle, the Army "obtains most of its information about protest politics from the files of municipal and state police departments and of the FBI. . . . [O]n occasion, [it] conduct[s] [its] own undercover operations." 27

The Army publishes an "eight-by-ten, glossy-cover paperback booklet known . . . as the 'blacklist.' . . . [It is] an encyclopedia of profiles of people and orgamizations who, in the opinion of the Intelligence Command officials who coinpile it, might "cause trouble for the Army." "28 The FBI, the Secret Service, the Passport Office, the CIA, the National Security Agency, the Civil Service Comunission, the Defense Intelligence Agency, the Navy, and the Air Force ${ }^{29}$ all have access to the Army's memory banks, which are probably kept at Fort Holabird, Maryland. ${ }^{30}$

\section{III}

\section{LEGAL ISSUES RAISED BY PREVENTIVE INTELLIGENCE SYSTEMS}

\section{A. Legal Challenges-Anderson v. Sills}

Suits to enjoin various aspects of pohice preventative intelligence operations are beginning to reach the courts. Most of the suits filed thus far have failed to survive defendant's notion to dismiss. ${ }^{31}$ Anderson v. Sills, ${ }^{32}$ a recent New Jersey case, is thus soinewliat exceptional.

inch index cards. The unit has several thousand such cards on file, each referring to a different activist in the Washington area.

The cards contain a picture of the person, his name, address, occupation and background, a list of the political groups to which he belongs, notes on pohtical ineetings and demonstrations he has attended and a summary of his views on political issues.

Id. at 20, cols. $3 \& 4$.

25. Pyle, supra note 16 , at 5 .

26. Id.

27. Id.

28. Id. at 6 .

29. Id.

30. Id.

31. In Aronson v. Giarrusso, Civil No. 66-281 (E.D. La.), the court dismissed a snit which sought, on first amendment grounds, to enjoin the New Orleans police from photographing every woman who got off the Woman's Strike for Peace trolley at Canal Street in 1967 and the photographing of every picket protesting the appearance of General Westmoreland at the Jung Hotel.

Federal District Judge George Hart, Jr., in Washington, D.C., dismissed a suit by the American Civil Liberties Union to prevent the Army from collecting, storing, and circulating information on the political activities of citizens. See S.F. Chronicle, Apr. 23, 1970, at 13, col. 1 .

32. 106 N.J. Super. 545, 256 A.2d 298 (Ch. 1969), rev'd, 56 N.J. 210, 265 A.2d 
Relying upon first amendment arguments, civil rights activists, suing for themselves and all others similarly situated, succeeded, at the trial court level, in obtaining a summary judgment and an mjunction against the state's intelligence gathering system ${ }^{33}$-only to have that judgment reversed by the New Jersey supreme court. The court remanded the case to the trial court ${ }^{34}$ for further proceedings leading to a decision on the merits. The facts of the case are enlightening.

Against the background of a decade of political unrest, and, im particular, ghetto disturbances within the state, the State Attorney General distributed a memorandum urging local police to use a system devised by the New Jersey State Pohice Central Security Unit to detail political protest activity and identify the participants. ${ }^{35}$ The system relies upon two forms to communicate information to a state bureau for evaluation and dissemimation: a Security Incident Form and a Security Summary Report Forn. ${ }^{36}$

The police use the Security Incident Forn to characterize and evaluate political incidents. Examples of incidents to be reported include "civil disturbance, riot, rally, protest, demonstration, march, confrontation, etc." 37 In each case, investigators are requested to indicate whether such an incident is anticipated, in progress, or has terminated, as well as the anticipated or actual date of the incident and its purposes, ${ }^{38}$ the names of any organizations or groups involved and the names and addresses of their leaders. ${ }^{39}$ The forn also calls for a characterization of involved organizations-suggested categories include left wing, right wing, civil rights, militant, nationalistic, pacifist, religious, Black Power, $\mathrm{Ku} \mathrm{Klux} \mathrm{Klan}$, and extremist-and an indication of the role played by each, either sponsor, co-sponsor, or supporter. ${ }^{40}$

Police agents use a Seeurity Summary Report ${ }^{41}$ to record myriad details about participants in the incidents: name, address, birthdate,

678 (1970). The superior court decision has been noted at 83 HARV. L. REV. 935 (1970); 22 Stan. L. Rev. 196 (1970); 23 Vand. L. Rev. 180 (1969); Clearinghouse Rev., Oct. 1969, at 130 and Nov. 1969, at 157.

33. 106 N.J. Super. 545, 546, 256 A.2d 298, 299 (Ch. 1969). Declaring the police practices unconstitutional, the trial court ordered the Attorney General to produce and destroy all pertinent forms and files. Id. at 558, 256 A.2d at 305.

34. 56 N.J. at 231,265 A.2d at 689.

35. See 106 N.J. Super. at 546, 256 A.2d at 299.

36. Id., $256 \mathrm{~A} .2 \mathrm{~d}$ at 300 .

37. 106 N.J. Super. at 558-62, 256 A.2d at 305-09 (app. A); 56 N.J. at 231-35, 265 A.2d at 690-93 (app. G).

38. 106 N.J. Super. at 558-62, 256 A.2d at 305-09 (app. A).

39. Id., 256 A.2d at 305-09 (app. A).

40. Id., 256 A.2d at 305-09 (app. A).

41. See id. at 562-66, 256 A.2d at $310-13$ (app. B); 56 N.J. at 235-39, 265 A.2d at $694-96$ (app. $G$ ). 
birthplace, marital. status, age, sex, race, and physical description. ${ }^{42}$ Also reported are the individual's employer, arrest record, State Bureau of Investigation and FBI numbers, motor vehicle record, driver's license number, and social security number. ${ }^{43}$ Instructions on the form direct the investigator to use a space marked "narrative" to record the individual's citizenship, parental background, draft status, meinbership or affiliation with organizations or groups, educational background, habits and traits, places frequented, parole record, data on his immediate family, credit rating, and a record of past activities, along with other findings or observations. ${ }^{44}$

The New Jersey supreme court considered the record presented on plaintiffs' motion for summary judgment exceedingly sparse. ${ }^{45}$ The constitutional issue, the court decided, was presented in a hypothetical way "within an aura of surmise and speculation." 46 The court did not find "an iota of evidence" 47 to support the plaintiffs" contention that the Attorney General's memorandum has operated to deter individuals from exercising their constitutional right to free speech. The court characterized the inemorandum as a suggestion, not as a regulation, directive, or order. ${ }^{48}$ In the court's view, therefore, it was improvident for the trial court to decide the inerits on so madequate a record. ${ }^{49}$

The court made several observations it thought would prove helpful to the trial court upon the remand. ${ }^{50}$ The court first recognized that the police have a legitimate objective in seeking to ascertain what forces, groups, and organizations could become "enmeshed im public disorders." A1 Allowing that upon remand it may well be established that some of the information on police forms is wholly unrelated and irrelevant to police obligations and functions, ${ }^{52}$ the court satisfied itself that information was not randomly disseminated but was "available to public agencies only on a 'need-to-know' basis" ${ }^{33}$ and refused to categorically strike down questionable aspects of the two forms. ${ }^{54}$

The remand offers the possibility of future success for the plaintiffs; nevertheless, it is clear that the court in Anderson took a restric-

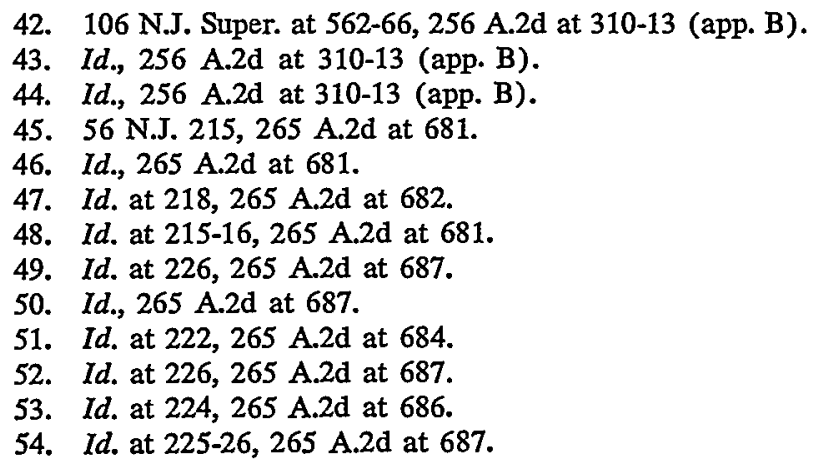


tive view of its role in this type of controversy. "It is a serious matter," the court suggested, "for the judiciary to interfere with the preventative measures devised by the executive branch of government in response to its constitutional obligation to protect all citizens." Weimtraub, writing for the court, said:

The total power of government is divided among the three branches to prevent despotic behavior within any of them. The delicate balance would be upset if the judiciary interfered with another branch upon nothing more than a fear that its officers will be unfaithful to their oaths or unequal to their responsibility. A public officer who intentionally turns his office to an arbitrary end is already accountable under the criminal law for such misconduct. ${ }^{56}$

The basic approach must be that the executive branch may gather whatever information it reasonably believes to be necessary to enable it to perform the police roles, detectional and preventive. A court should not interfere in the absence of bad faith or arbitrariness. ${ }^{57}$

This restrictive mterpretation of the court's role in adjudicating the issues raised by the police practices outlined above is the most significant aspect of Anderson and will be evaluated in later sections. ${ }^{68}$ First, however, it is necessary to clearly define the issues raised by preventative intelligence systems.

\section{B. Governmental Interest Versus Encroachments on Civil Liberties}

The possible governmental interests prompting law enforcement officials to compile dossiers range from blunting threats of civil disorder to preventing the assassination of key government officials. Assuming for the moment that preventative intelligence can materially lessen the risks that such events will occur, no one, except perhaps the hardened revolutionary, can deny the desirability of preventing and minimizing acts of violence and terror, which, at the extreme, paralyze constituted authority and undermine in an intolerable manner constitutional processes for change and redress of grievances. The goal of preventativc intelligence is to know, before such incidents occur, the groups and individuals demonstrating a propensity for launching such acts of terror on the theory that the civil disorder can thus be prevented. But the Umited States Supreme Court, in Shelton v. Tucker, ${ }^{\text {60 }}$ has made it

55. Id. at $225,265 \mathrm{~A} .2 \mathrm{~d}$ at 686 .

56. Id. at 229,265 A.2d at 689 .

57. Id., $265 \mathrm{~A} .2 \mathrm{~d}$ at 688 .

58. See text accompanying notes 82-126 infra.

59. 364 U.S. 479 (1960). This case involves the constitutionality of an Arkansas statute requiring all teachers employed in state schools and colleges to file, as a condi- 
clear that "even though the government interest be legitimate and substantial, that purpose cannot be pursued by means that broadly stifle fundamental personal liberties when the end can be more narrowly achieved." ${ }^{\circ 0}$ Under Shelton, a court inust carefully examine not only the government's interest in a given statute, regulation, or practice but also the means chosen to further that interest, and if those means stifle fundamental liberties, and narrower means are available, the government practice must be curtailed. When no narrower means are available, however, the court faces a difficult decision. It must either allow encroachment into protected areas of personal liberty or seriously hamper the government from pursuing its legitimate interests.

The initial relevant question, then, is whether preventative intelligence systems "stifle fundamental liberties." Although it is unlikely that lawful expression and association is immediately and directly suppressed by virtue of such systems, there are an array of related disturbing consequences which can flow from the establishment of a preventative intelligence system. In the language of first amendment adjudication, these consequences can be characterized as having a "chilling effect" ${ }^{01}$ on protected activity. While discussions of chilling effect can be conclusory, subjective, and not very precise, ${ }^{02}$ it is a concept which las received recognition by the Court and is susceptible to reformulation as a useful standard of adjudication.

In this instance, the relevant question is whether, as a consequence of the establishment of a preventative intelligence system, open discussion and airing of opinions are enhanced or curtailed; whether zones of personal and associational privacy are expanded or foreshortened. The first amendment limits the actions of government so as to msulate discussion of political and social issues and make possible an informed electorate. ${ }^{63}$ The first amendment achieves this in part by protecting

tion of employment, an affidavit detailing all organizations to which they belonged or contributed within the preceding five years. Declaring the act unconstitutional, the Court stated, "[the act's] comprehensive interference with associational freedom goes far beyond what might be justified in the exercise of the state's legitimate imquiry." Id. at 490.

60. Id. at 488 .

61. See, e.g., Lamont v. Postmaster General, 381 U.S. 301 passim (1965); Dombrowski v. Pfister, 380 U.S. 479 passim (1965); NAACP v. Button, 371 U.S. 415 (1963); Talley v. California, 362 U.S. 60 passim (1960); Sweezy v. New Hampshire, 354 U.S. 234 passim (1957).

62. What may chill one man may not deter another. There exist, undoubtedly, committed individuals who will not be deterred by such pohice activity. Does chilling effect refer, then, to the possible deterrent effect an activity will have on a timid housewife or a wishy-washy liberal who balks when the going gets rough? Even if the standard is in terms of a reasonable man, it remains essentially subjective.

63. See A. MeIklejohn, Free SpeEch and Its Relation to Self-Government (1948), for discussion of the reasons for the free speech provisions of the Constitution. 
an individual's personal right of expression and in part by creating a zone of privacy around the freedom of the individual to associate with others in exercising his right of expression. The Court has recognized that "[e]ffective advocacy of both public and private points of view, particularly controversial ones . . . is undeniably enhanced by group association." ${ }^{\circ 4}$ Justice Brennan, in NAACP v. Button, ${ }^{85}$ speaks of "breathing space"60 necessary for the exercise and survival of first amendment freedoms in situations where threat of sanction, and, presumably, "other manifestations of public hostility," may extinguish or diminish expression. This breathing space is achieved by maintaining an "[i]nviolability of privacy in group association which may in many circunistances be indispensable to preservation of freedom of association, particularly when a group espouses dissident behiefs." 08 These circuinstances, in NAACP v. Alabama ex rel. Patterson, can be best suinnuarized as sanctions, threat of sanctions, manifestations of public hostility, or, more simply, special consequences attaching to the expression of unpopular or minority viewpoints.

By inferrence fron $N A A C P$ v. Alabama ex rel. Patterson one can say that freedoni of expression is not enhanced, and the purposes of the first amendment is not served, if state or federal police, by their surveillance and reporting, attach detrimental consequences to the expression of some political viewpoints that do not attach to other viewpoints. An analysis of the possible effects of the New Jersey system ${ }^{60}$ serves graphically to illustrate the possible consequences: groups and individuals participating in selected free speech activities (those of interest to the police) are potential subjects of a police report. Participants' names, employers, associates and organizations may be preserved in a dossier; the nranifestations of their political beliefs are relevant niaterials for a file.

That this consequence attaches to the legal expression of ninority viewpoints or participation in legal political activity suffices in itself to call into question whether such police activity undermines in a unreasonable and impermissible nuanner the purposes of the first amendnient. ${ }^{70}$ Further speculation as to the possible effect such consequences nray have on the quantum of political expression is perhaps unnecessary for purposes of framing a litigable issue. However, such speculation

64. NAACP v. Alabama ex rel. Patterson, 357 U.S. 449, 460 (1958).

65. 371 U.S. 415 (1963).

66. Id. at 433.

67. NAACP v. Alabama ex rel. Patterson, 357 U.S. 449, 462 (1958).

68. Id.

69. See text accompanying notes 35-58 supra.

70. Cf. Lamont v. Postmaster General, 381 U.S. 301 (1965); Shelton v. Tucker, 364 U.S. 479 (1960); NAACP v. Alabama ex rel. Patterson, 357 U.S. 449 (1958). 
makes the undermining of the first amendment more palpable.

Knowledge or suspicion that one's activities and associations are subject to pohice scrutiny and record will tend to produce fears which may prevent or impede participation in unpopular causes or suspect political activity. Those fears emanate from the ambiguity and uncertainty surrounding the eventual use of the information on file. It is possible that the files will remain untouched and inactive year after year; it is also possible that the information will be retrieved and used at a future time, and one has no assurances as to what the future use will be. The information is a skeleton outline of a man's activities and thoughts-political and otherwise-which can be used to reconstruct an incoinplete and possibly inaccurate picture of that individual. If it could be guaranteed that the recorded data would only be used in proper forums with adeqate safeguards the fears would be lessened. But even this guarantee is not available.

There is, it seems, no limit on the use to which these files may be put, save the consciences of those who have access to them, and so these dossiers are, in effect, time bombs. There is no telling when they may detonate or, because they contaim so many 'related' names, who may be injured when they do explode. ${ }^{71}$

Further, the dossiers "have an enduring quality": ${ }^{22}$ they are filled with 'facts' an individual has no opportunity to question or to rebut. One does not have the opportunity to supply missing details which round out or put in a different light acts which have been recorded. Since those with whom one associates are included in the file, "anyone even remotely connected with a questionable person may himself become tainted $^{73}$. . . . Since the compilers of these files appear to be consummately skilled cross-indexers, especially since the advent of the computer, the dossiers often become links in virtually endless cliains of guilt." "74

If authorized circulation of information in dossiers is frightening, an unauthorized leak is even more so. The information on file is no inore secret than the number of individuals having access to the dossiers wish to inake it. ${ }^{75}$ With information flowing from local police

71. Stern, supra note 17 , at 37 .

72. Id.

73. Id.

74. Id.

75. The following two examples involved supposedly secret, nonpolitical files:

In a campaign speech he made when he was Vice President, Richard Nixon quoted from a Naval Intelligence security report, based on data received from the FBI, to discredit and contribute to the defeat of a Democratic Congressman.

A secret Army Counter Intelligence investigation of a retired Army brigadier general came to light in the inidst of a political campaign, and he was forced to withdraw as Republican candidate for Congress. 
to state central security agencies, who in turn pass information on to the federal agencies, who in turn are willing to share what is on file, ${ }^{70}$ the opportunities for unauthorized leaks are manifold. A politically active person has strong grounds to believe that even the strictest standards imposed for authorized disclosures cannot prevent unauthorized leaks. Thus, it can be seen that freedom of expression is not enhanced by the operation of preventative intelligence.

Similarly, zones of privacy are foreshortened and not expanded by police surveillance. The right to privacy is not specifically guaranteed by the Constitution or the Bill of Rights. However, the Supreme Court has repeatedly recognized a right to privacy shared by both imdividuals and groups. Justice Douglas, writing for the majority in Griswold v. Connecticut, ${ }^{7 \tau}$ speaks of penumbras emanating froin the specific guarantees of the Bill of Rights that give those guarantees "life and substance."78 "Various guarantees create zones of privacy."78

The existence of dossiers enumerating the participants in selected political activities along with the names of the participants' associates and group affiliations arguably invades the right to privacy. It is true that in all phases of life privacy has diminished as advances in cominumication and transportation break down the barriers which once isolated one inan's thoughts and acts from others. Advances in record keeping and data processing permit preservation of a man's thoughts and acts long after the events giving rise to those thoughts and acts occur. Perhaps the amount of privacy one might desire is an anachronism-excess cultural baggage from an earlier time inappropriate in today's civilization. 'It is also possible that privacy is an expanding and not a diminishing concept; a right not duly appreciated at a time when one man's thoughts and actions were isolated from another. Perhaps it is a right that has become inore precious as it becomes more rare. In any event, it is a right which has received strong and increased recognition by the Supreme Court and one which no student of constitutional law can take lightly.

Stern, supra note 17 , at 38 . See also Pyle, supra note 16 , at 13 .

Only last year, information from the Army's confidential service record on New Orleans District Attorney Jim Garrison was leaked to the press. Officers at the Investigative Records Repository at Fort Holabird (which functions as the Army's lending library for such files) suspected that the leak came from a civilian agency in Washington. They were helpless to do anything about it, however, because they had no system of records accountability by which they could fix responsibility.... [O]ne officer [said] "We probably couldu't Id. stop it [the leaks] if we tried."

76. See text accompanying notes 15 \& 36 supra.

77. 381 U.S. 479 (1965).

78. Id. at 484.

79. Id.; cf. NAACP v. Button, 371 U.S. 415 (1963); NAACP v. Alabama ex rel. Patterson, 357 U.S. 449 (1958). See also text accompanying notes 65-70 supra. 
It can be argued that recordation of an individual's political activities and beliefs does not invade privacy. Deinonstrating and marching in public places and speaking at public meetings arguably indicates the actor's willingness to be noted and identified with a cause. Participation in public events entails the risk or possibility of recognition.

This line of reasoning overlooks an obvious aspect of human nature: a person does not necessarily vacillate between a desire for absolute privacy and absolute exposure. ${ }^{80}$ An individual may desire to maintain different levels of anonymity in different contexts. Although the Supreme Court has not spoken to the amount of privacy to which one may be entitled, it would be anomalous-given that the various freedoms in the Bill of Rights reinforce one another-if that amount of privacy were less than is necessary to foster free expression and association.

The feeling that one's politics are subject to scrutiny and notation by the police may rest uneasily with many individuals. "When a person knows his conduct is visible, he must either bring his actions within the accepted social norms in the particular situation involved or decide to violate those norms and accept the risk of reprisal." 11 Having the police as the arbiter of these social norms, for reasons to be discussed below, is an uncomfortable sensation to many. Even when acts are voluntarily performed in public, the idea that a Big Brother is watching even 'innocent' activities is abhorrent. One can reasonably conclude that privacy is foreshortened when police watch and record.

\section{The Role of the Court in Dossier Cases}

The only apparent source of authority to the New Jersey pohice to establish its preventative intelligence system is a memorandum by the State Attorney General urging local police to use the Security Report and Security Incident forms and communicate the information so gathered to a state central security unit. ${ }^{82}$ The forms themselves, and the information they request, had apparently never been exphicitly approved or deemed necessary and warranted by the executive or legislative branches. $^{83}$ Thus, this case presents constitutional issues not present in the normal first ainendment case.

80. See Shils, Privacy: Its Constitutionality and Vicissitudes, 31 LAw \& CoNTEMP. Proв. 281 (1966). The article discusses how the desire for anonymity differs in varying contexts.

81. A. Westin, Privacy and Freedom 58 (1967).

82. - N.J. at -, 265 A.2d at 681.

83. The only link discovered between the New Jersey Governor and the preventative intelligence system is that the memorandum was sent to all police units following a conference between the Governor and the mayors of the municipalities of the State. Id. at $\longrightarrow, 265$ A.2d at 681 . 
The task of the court in normal cases involving a clash between legitimate governmental interests and freedoms protected under the Bill of Rights is to balance the substantiality of the state's interests against the incursions on protected freedoms occasioned by the means cliosen to pursue those interests. The court announces standards for deciding which imcursions on these freedoms are permissible.

Implicit in this balancing process is a deference by the court to the determinations of the policy-maker, usually a legislature. That deference flows from an assumption that the governmental policies and the inanner in whicl suclı policies are vindicated have been competently and reasonably determined. If that deference is withheld because the policy-maker is somehow incompetent or not sufficiently politically responsive, the court may well refuse to balance, holding in abeyance an adjudication on the merits until the processes leading to a competent and responsible determination, meriting deference, are completed. ${ }^{84}$

There are two primary reasons why this usual deference should not be shown in the dossier cases presented thus far. First, the policy-makers involved liere are law enforcement officials and not legislators or administrators explicitly entrusted with quasi-legislative powers: in other words, the police are not as competent as legislators to make needed policy determinations in this area. Second, the police are neither a pohitically responsive imstitution nor a co-equal branch of government: they are not directly responsible to a broadly-based constituency or electorate. They do not derive their powers by means of delegation from a fundamental document orgamizing government such as a constitution: the power of the police is derived from delegations of power to them by the legislative and executive branches of government.

\section{Legislative v. Police Determinations: Competence}

A first amendment controversy typically involves the constitutionality of a legislative enactment. ${ }^{85}$ In sucl cases, the courts traditionally

84. Cf. United States v. Robel, 389 U.S. 258 (1967); Watkins v. United States, 354 U.S. 178 (1957). See also Bickel, The Passive Virtues, 75 Harv. L. Rev. 40 (1962).

This refusal to adjudicate is similar to the way the court functions when faced with a vague or broadly worded statute enabling the administrator of that statute to act with nearly unchecked discretion.

When the court declares the statute void for vagueness, it withholds adjudica-

tion of the substantive issue in order to set in motion the process of legisla-

tive decision. It does not hold that the legislature may not do whatever it is that is coinplained of, but rather asks that the legislature do it, if it is to be Id. at 63 .

done at all.

85. See, e.g., Shelton v. Tucker, 364 U.S. 479 (1960); and the cases involving the Smith Act, e.g;, United States v. Robel, 389 U.S. 258 (1967); Scales v. United States, 367 U.S. 203 (1961); Communist Party v. Subversive Activities Control Board, 367 U.S. 1 (1961); Dennis v. United States, 341 U.S. 494 (1951). 
are careful to avoid overstepping their bounds by directly or indirectly questioning the wisdom of the enactment. This judicial self-restraint is based, in part, on the practical consideration that the legislature is more competent to decide the necessity for legislation than is the judiciary.

Such coinpetence is based in large part upon the legislature's having at its disposal mechanisms to make it an expert fact gathering and evaluating body. Legislative committees have subpoena power; they may conduct "inquiries concerning the administration of existing laws as well as proposed or possibly needed statutes." surveys of defects in our social, economic or political system for the purpose of enabling Congress to remedy them. . . . It is unquestionably the duty of all citizens to cooperate with the Congress in its efforts to obtain the facts needed for intelligent legislative action. It is their unremitting obligation to respond to subpoenas . . . to testify fully with respect to matters within the province of proper investigation. ${ }^{87}$

The court does not have the same broad fact gathering power which assures a measure of expertise in making broad policy decisions. "The more fundamental the issue, the nearer it is to principle, the more important it is that it be decided in the first instance by the legislature." 88 Therefore, the court declines to function as a super-legislature and gives deference to legislative determinations, affording those determinations a presumption of constitutionality. ${ }^{89}$ In fact, except wliere specially protected freedoms such as free speech and religion are involved, a court requires no more than a rational basis to support a legislative act. ${ }^{90}$

However, to whatever extent the court's deference is based on the superior fact-finding ability of the legislature, cases involving legislative enactments afford no compelling precedent for extending the sanie deference to decisions made by police agencies. The police-or Army for that matter-do not typically have the resources to conduct the thorough factual inquiry which is prerequisite to making broad policy decisions.

But even if they had those resources it is still questionable whether their determinations deserve deference. The reason for this is that competence requires not only the ability to find the facts, but also the

86. Watkins v. United States, 354 U.S. 178, 187 (1957).

87. Id. at 187-88.

88. Bickel, supra note 84 , at 68 .

89. Cf. Communist Party v. Subversive Activities Control Board, 367 U.S. 1 (1961).

90. Cf. Breard v. Alexandria, 341 U.S. 622 (1951); Railway Express Agency v. New York, 336 U.S. 106 (1949). 
ability to make objective non-biased decisions based on those facts. The police, because of their primary role, cannot be called upon to vindicate two often conflicting interests: enforcing law effectively and enforcing law constitutionally. In the first place, the police-unlike the courts or the legislature-are acting outside the scope of their professional competency when called upon to decide questions of constitutional law. The police are responsible for vindicating society's interest in thwarting crime. The policeman, as a professional, is trained to identify the criminal, recognize when a crime is being committed, know how best to inake an arrest, and decide wliat degree of force is necessary to stop a criminal. ${ }^{91}$ These are different responsibilties from those entrusted to a legislature or court. The policeman is not chargcd with the duty of legislating what acts are crininal, deciding where free speech must be abridged for the preservation of civil order, or guarding against possible unconstitutional ramifications of their definitions and decisions.9 ${ }^{92}$

The problem of coinpetency is aggravated by the problem of obtaining an unbiased decision where the decision maker is under strong pressure to decide questions in a particular way. Police have the primary duty to tliwart crime effectively; their judgments are thus understandably colored by the exigencies of emergency. In their view, any characteristic or act triggering suspicion may be the seeds of an illegal act. $^{.3}$ The police, then, are teinpted to set in motion investigations based on the broadest possible incriminating circumstances or generalizations. The police, by the nature of their function in society, favor the use of systems which weigh the odds heavily in favor of trapping all illegal conduct. If the end to be sought is early identification of all possible sources of civil disorder, dossiers on all activists might weigh the odds more heavily in the policeman's favor than, for example, dossiers on violence-prone individuals only. The legislature, on the other hand, lias the responsibility and, by implication, the ability to make such broad policy decisions and to do so constitutionally. A legislature is expected to give its laws scrutiny for constitutionality that agencies like the police are not likely to give their programs.

Thus, the deference that a court gives to the legislature concerning the probable constitutionality of their acts need not be given to law enforceinent officials. "It would . . . be liard to state a sound politi-

91. Professionalism implies the ability, due to special training and experience, to handle certaim assigned responsibilities more competently than laymen.

92. Certainly, the court defers to the competence of the police to make certain determinations. See text accompanying note 91 supra. Such instances differ greatly, however, from a case where the police must determine not only whether the factual situation meets a constitutional standard but also must determine the standard as well.

93. Cf. Johnson v. United States, 333 U.S. 10 (1948). 
cal reason for the judicial branch's doing anything but walking into such a case with no presumptions of constitutionality whatever, with no apparatus of judicial self-denial."

Precedent exists for the proposition that policy decisions of agencies like the police, acting outside their splere of responsibility, need not be given the same deference as legislative determinations. In National Student Association v. Hershey, ${ }^{95}$ the court struck down a directive issued by the liead of the Selective Service which, in effect, gave local draft boards the power to decide what is or is not legal political activity. ${ }^{96}$

It is no reflection on the competence or integrity of selective service personnel to observe that they are ill-equipped to determine questions of law as delicate and complex as those commonly raised by antiwar protest activity .... [B]y entrusting to draft boards effective power to decide the hard legal and constitutional questions for theinselves, the directive seriously compounds [the] chilling effect on protected conduct. ${ }^{97}$

Likewise, it is no reflection on the conpetence of the police in performing the crime-control function, to suggest that they are similarly illequipped to make the policy decision that dossiers on political activists they consider dangerous are necessary for the preservation of law and order.

\section{Legislative v. Police Determinations: Political Responsiveness.}

In addition to lack of competence to make broad policy decisions, the police-and the FBI and Army-are not politically responsive institutions. Aspiring policy nrakers within those organizations are not elected officials. They are not directly accountable to those governed but are only responsible, directly or indirectly, to elected officials. The naking of broad policy decisions, or law, by men not directly ac-

94. C. Black, JR., Structure and Rrlation in Constitutional LaW 78 (1969) [hereinafter cited as BLACK]. Black makes this comment in regard to Massiah v. United States, 377 U.S. 201 (1964), a case involving the admissibility of evidence gathered by means of a radio transmitter planted in defendant's car by government officers while defendant was out on bail on a narcotics indictment. Black points out that had the court deferred to the judgments of investigators and prosecutors in this case, the defendant would never get a competent judgment on the constitutionality of "what has been done to him ... from anyone except his formal adversaries in the criminal process." C. BLACK, JR. supra. The same reasoning is applicable to police dossiers where the constitutional judgments have been made by investigators and prosecutors.

95. 412 F.2d 1103 (D.C. Cir. 1969).

96. Selective Service delinquency regulations permit local boards to reclassify a registrant the board declares to be a delinquent. The Hershey directive, contained im Local Board Memorandum No. 85, declared that a local board, upon deciding that a registrant participated im an illegal demonstration, may reopen the classification of the registrant and classify him anew in accord with the delinquency regulations. Id. at 1116-18.

97. Id. at 1118. 
countable to those governed when they are acting under an explicit mandate from a politically responsive delegator is, of course, not uncommon. ${ }^{98}$ However, the making of broad policy by a nonelected body when acting without a mandate or under an mexplicit mandate runs, to some extent, counter to a policy to vest the sole power to determine such policy in a legislature..$^{99}$

The legislative is not only the supreme power of the commonwealth, but sacred and unalterable im the hands where the community have once placed it; nor can any edict of anybody else, in what form soever conceived or by what power soever backed, have the force and obligation of a law which has not its sanction from that legislative which the public has chosen and appointed; for without the law law could not have that which is absolutely necessary to its being a law: the consent of the society over whom nobody can have a power to make laws, but by their own consent and by authority received from thein. ${ }^{100}$

The court defers to legislated law which, in theory, represents the will of the majority. Likewise, the court extends deference to the executive brancli. ${ }^{101}$ The executive is an elected official entrusted with the responsibility of implementing law: therefore, the court affords an executive's decision of how best to implement a law the same presumptions of constitutionality that it affords a legislative act. ${ }^{102}$ Except where specially protected freedoms are involved, no more than a rational basis is necessary to support an executive decision. ${ }^{103}$ Especially in areas of doubtful constitutionality, it is desirable to have the policy made where there is the "crucial joinder between power and broadly based, democratic responsibility, bestowed and discharged after the fashion of representative government."104

Unwillingness to grant sucl policy-making powers without explicit delegation to politically unresponsive officials is reflected in Greene v. McElroy. ${ }^{105}$ In that case, the Supreme Court presumed, in

98. The Securities and Exchange Commission, for example, promulgates rules which, in essence, are law. This is true of other administrative agencies specifically delegated authority to enact certain rules or laws. See K. Davis, AdmINISTRATIVE LAW (1959).

99. See text accompanying notes 101-03 \& 113-17 infra. The policy referred to is the constitutional scheme to establish three co-equal branches of government with differing powers and responsibilities.

100. J. Locke, The Second Treatise of Government \ 134 (1690).

101. Cf. Joint Anti-Fascist Refugee Comm. v. McGrath, 341 U.S. 123 (1951).

102. Cf. id.; Greene v. McElroy, 360 U.S. 474 (1959).

103. Cf. Greene v. McElroy, 360 U.S. 474 (1959); Joint Anti-Fascist Refugee Comm. v. McGrath, 341 U.S. 123 (1951).

104. BICKEL, supra note 84 , at 67-68.

105. 360 U.S. 474 (1959). This case involves the revocation of a security clearance of an aeronautical engineer employed by a private manufacturer producing goods for the armed services. The security clearance program and its procedures were established by directives issued by the Secretary of Defense and were not a creature of statute or executive order. 
the absence of a clear showing to the contrary, that a security clearance procedure established by the Department of Defense ${ }^{106}$ was not authorized by the President or Congress. ${ }^{107}$ The Secretary of Defense, and his subordinates, like police officers and FBI administrators, are not elected officials. A broadly worded or vague delegation of power ${ }^{108}$ "necessarily delegates the power of ad hoc decision to [such] officials. And so the official's action . . . does not represent the will of the state expressed through the political process." ${ }^{109}$ The official or administra-

106. The procedures denied the petitioner the traditional procedural safeguards of confrontation and cross-examination. 360 U.S. at 507.

. 107. The Court stated the proposition that acquiescence or implied ratification by the President or Congress of sucl 1 admmistrative procedures in areas of doubtful constitutionality is insufficient to allow the court to reach the merits of a case. Id.

108. The discussion assumes that the delegation of authority to the New Jersey police, as well as to the FBI, Secret Service, and Army, is broadly worded and vague. See text accompanying notes 83-84 for data supporting this assumption with regard to the New Jersey police. The Report of the Warren Commission provides some basis for the assumption that the delegation of authority to the Secret Service and FBI is also somewhat broadly worded and vague.

The Secret Service was organized as a division of the Department of the Treasury in 1865, to deal with counterfeiting. In 1894, while imvestigating a plot to assassinate President Cleveland, the Service assigned a small protective detail of agents to the White House. ... These informal and part-time arrangements led to more systematic protection in 1902, after the assassination of President McKinley; the Secret Service, then the only Federal investigative agency, assumed full-time responsibility for the safety of the President. Since that time, the Secret Service lias liad and exercised responsibility for the plysical protection of the President and also for the preventive investigation of potential threats against the President.

Althougl the Secret Service has liad the primary responsibility for the protection of the President, the FBI, which was established withm the Department of Justice in 1908, has had in recent years an increasingly important role to play. In the appropriations of the FBI there las recurred annually an item for the "protection of the person of the President of the United States," whicl first appeared in the appropriation of the Department of Justice in 1910 under the lieading "Miscellaneous Objects." Althougl the FBI is not charged with the pliysical protection of the President, it does have an assignment, as do other Government agencies, in the field of preventive investigation in regard to the President's security.

WARREN COMMISSION REPORT, supra note 6, at 434.

According to Pyle, the delegation of authority to the Army for preventative intelligence activity is even more tenuons:

According to the Nixon Administration, authority for this kind of program coines from the Constitution. So, at least, the Justice Department claimed last June in a brief defending the FBI's failure to obtain searcl warrants before tapping telephone calls of . . . the "Chicago Eiglti." The Justice Department argued that Article Two of the Constitution authorizes the President and his agents to engage in whatever "imtelligence-gathering operations he believes are necessary to protect the security of the nation" and that this authority "is not dependent upon any grant of legislative authority from Congress, but rather is an inherent power of the President, derived from the Constitution itself." Thus, the Department conteuded, "Congress cannot tell the President what means lie may employ to obtain information lie needs to determine the proper deployment of his forces."

Pyle, supra note 16 , at 5.

109. Bickel, supra note 84 , at 63 . 
tor or police officer is allowed to define his own authority, " to cloose the direction and focus of [his activities]." "110

Chief Justice Warren, writing for the majority in Greene, disparaged the Defense Department security procedures saying:

Such decisions cannot be assumed by acquiescence or non-action . . . They must be made explicitly not only to assure that individuals are not deprived of cherished rights under procedures not actually authorized . . . but also because explicit action, especially in areas of doubtful constitutionality, requires careful and purposeful consideration by those responsible for enacting and implementing our laws. Without explicit action by lawmakers, decisions of great constitutional import and effect would be relegated by default to administrators who, under our system of government, are not endowed with authority to decide them. ${ }^{111}$

Clearly, a decision to establish a preventative intelligence system with its necessary imcursions into first amendment and privacy rights is a decision of "great constitutional import and effect."112 If the New Jersey systein is representative of preventative intelligence systems, then equally clearly the silence, or, at best, the vague delegation of authority by an executive or legislature to the attorney general and police to define what politics are dangerous and how to combat them does not merit much deference by a court. Therefore, im areas where procedures and decisions compromise specially protected rights such as free speech, the court should not, and has not, extended deference if the delegation of authority is not clear and explicit and if the procedures and decisions lave not been held necessary and warranted by those elected officials responsible for enacting or implementing law. ${ }^{113}$

The reason for not extending deference in this situation is readily apparent. The delegator himself lias not made the decision that the actions of the delegate are necessary and thus the court runs no risk of overstepping its bounds by countering a decision the Constitution reserves for another co-equal brancli of the government. ${ }^{114}$ The court, in this awkward situation, can refuse to defer to the police; striking down the procedures making incursions into specially protected rights, while at the same time loolding in abeyance a determination on substantive issues until processes leading to a competent, deference-meriting, determination are coinpleted. ${ }^{115}$

110. Id. at 67.

111. 360 U.S. at 507.

112. Id.; see text accompanying notes 59-81 supra.

113. Cf. Greene v. McElroy, 360 U.S. 474 (1959).

114. See text accompanying note 82 supra.

115. See Bickel, supra note 84, at 40 . See also United States v. Robel, 389 U.S. 258 (1967); Greene v. McElroy, 360 U.S. 474 (1959); Watkins v. United States, 354 U.S, 178 (1957). 
This process is analogous to the manner in which the Supreme Court, in Watkins $v$. United States, ${ }^{116}$ set aside the contempt conviction of a union officer for refusal to answer questions posed by the House Un-American Activities Subcommittee:

It is, of course, not the function of this Court to prescribe rigid rules for the Congress to follow in drafting resolutions establishing investigating committees. That is a matter peculiarly within the realm of the legislature, and its decisions will be accepted by the courts up to the point where their own duty to enforce the constitutionally protected rights of individuals is affected. An excessively broad charter, like that of the House Un-American Activities Committee, places the courts in an untenable position if they are to strike a balance between the public need for a particular interrogation and the right[s] of citizens. . . . It is impossible in such a situation to ascertain whether any legislative purpose justifies the disclosures sought and, if so, the importance of that information to the Congress in furtherance of its legislative function. The reason no court can make this critical judgment is that the House of Representatives itself has never made it. Only the legislative assembly initiating an investigation can assay the relative necessity of specific disclosures. ${ }^{117}$

And this same process should be employed to strike down an intelligence system on the New Jersey model: a system which, as it is conceived of and operates, is not the product of explicit delegation from or approval by the executive or legislative branches at their highest, most politically responsible, level; a system which comes "under the Court's hand not blessed, in any recognizable way, by any coordinate political authority."118

\section{Legislative v. Police Determinations: Vague Standards for Data Collection}

The creators of preventative intelligence systems do not articulate explicit standards to guide the police. ${ }^{119}$ The police, then, are left to fall back on their own resources, to "choose the direction and focus"120 of their own activity: they decide who is a political activist, who should be watched, what activities should be covered. They are responsible to no one-except perhaps the court when their practices are challengedto show how the myriad details put into dossiers will aid the government in materially blunting the threat of disorders and riots and that

116. 354 U.S. 178 (1959).

117. Id. at 205-06.

118. C. BLACK, JR., supra note 94 , at 81.

119. For example, the Sills memorandum is presumably self-explanatory: neither the superior court or supreme court opinions in Anderson refer to any materials aiding the police in the use of the Security Summary and Incident Report Forms.

120. Watkins v. United States, 354 U.S. 178, 205 (1957). 
the consequential incursions on freedoin of speech and privacy are justified in the circumstances.

The classifications used in preventative intelligence systems are vague. The undefined terms include "subversive," "activists," "malcontents," "left-wingers," "right-wingers."121 As Justice Douglas suggests in his concurring opinion in Joint Anti-Facist Refugee Committee v. McGrath, ${ }^{122}$

The charge that ... organizations are "subversive" could be clearly defined. But how can anyone in the context of the Executive Order say what it means? . . . Does it mean an organization with socialist ideas? There are some who lump Socialists and Communists together. Does it mean an organization that thinks the lot of some peasants have been improved under Soviet auspices? . . .

No one can tell ... what meaning is intended. ... The charge is flexible; it will mean one thing to one officer, another to someone else. It will be given meaning according to the predilections of the prosecutor: "subversive" to some will be synonymous with "radical"; "subversive" to others will be synonymous with "commumist." It can be expanded to include those who depart from the orthodox party line- to those whose words and actions (though completely loyal) do not conform to the orthodox view on foreign or doinestic policy. . . . Since they are subject to grave abuse, they have no place in our systein of law. When we employ them, we plant within our body politic the virus of the totalitarian ideology which we oppose. ${ }^{123}$

The inore imprecisely the police define the class of people whose names, activities, and characteristics are put in dossiers, the greater is the potential number of people subject to surveillance and the consequential incursions on their basic freedoms. The broad identification of characteristics and generalizations which set the police in motion need not be accepted by the courts. The court has the responsibility of setting standards to insure that the means employed do not run afoul of the Constitution. ${ }^{124}$

Admittedly, selection of characteristics which will have high probative value for purposes of predicting future behavior is the job of the social scientist. It is beyond the scope of the court, yet within the scope of the legislature, to try to find out what characteristics correlate in a significant manner to a propensity to cause civil disorder. For purposes of judging the necessity of police dossiers, the court can only guess as to whether the underlying generalizations used to justify the

121. See text accompanying notes 11 \& 40 supra.

122. 341 U.S. 123 (1951).

123. Id. at 176-77.

124. See text accompanying notes 59-60 supra. See also United States v. Robel, 389 U.S. 258 (1967). 
system are verifiable. ${ }^{125}$ However, when a system is not established or blessed by a competent fact-finding and policy-making body, responsive to the will of the people, there is insufficient assurance that the system has been exposed, weighed, and tested for the court to defer to the state's judgment. It should require the state to come up with more precise generalizations and characteristics, more convimcingly validated, and arrived at through processes expressing the will of those governed through the political machinery. ${ }^{126}$

\section{III}

\section{SUGGESTED STANDARDS FOR PREVENTATIVE INTELLIGENCE SYSTEMS}

Constitutional questions concerning the necessity and efficacy of preventative intelligence systems should be resolved before every state and local police force decides to institute sucli systems. If they must be used, ${ }^{127}$ the state should be required to limit the class of individuals whose activities inake them targets for a police dossier and to establish standards for the storing and circulating of the materials in dossiers to reduce the incursions on rights to privacy and free speech.

Limiting the class of individuals, and defining that class with precision, would serve to reduce the sweep of such systems. If, for example, the standard adopted called for reporting on individuals and groups advocating the use of force or law violation where it is reasonable to assume such advocacy significantly increases the likelihood that lawless action will obtain, the use of dossiers would be more carefully circumscribed. Such a standard would tend to neutralize any political bias which infects the dossier-coinpiling agencies.

125. The generalization underlying the state interest in a preventative intelligence system must be that political activists as a class are more likely than others to cause disorders and riots. This generalization may be validated against a low standard of proof for purposes of convincing one's neighbor that all activists are troublemakers, but when that same generalization is used to underpin a system under which all activists become subject to surveillance and data banks, it should be validated against a higher standard of proof. Cf. United States v. Robel, 389 U.S. 258 (1967).

126. Id.

127. That the dossier is an effective police tool is a highly questionable proposition. Except where the Secret Service needs a list of potential assassins in order to guard the President and other high governmental officials, it is unclear what use can be made of dossiers on political activists-a term which in itself is so vague as to be susceptible to multiple subjective meanings. Underlying the belief in dossiers nnust be a theory that civil disorder, riots, and demonstrations result exclusively or in large part from the machinations of a few conspiratorial groups of individuals and that civil order will obtain if these groups and individuals are closely watched and stopped before they act. See note 5 supra. Such a theory runs counter to studies which tend to prove that economic and political conditions, rather than a conspiracy, produce discontent, disorder, and riot. See, e.g., Report of the National Advisory Commssion on Civil DisORDERS 201 (Bantam ed. 1968). 
Free speech also suffers when people fear that inaccurate and incoinplete information stored in files will leak at a future time. ${ }^{128}$ Standards governing access to data can reduce such fear. The reasons for collecting information for dossiers do not necessarily correlate to reasons for retrieval of those particular items. The dossier on individuals who have threatened the life of the President inay have to be retrieved by the Secret Service agent needing to know who, in a given area, is a potential threat when the President comes to town. However, it is likely that at present, information collected for one purpose may be retrieved and used for a different purpose at a later time. Thus, it is conceivable that information on file with the FBI concerning an individual's threat to kill the President may be dumped into the hands of the Internal Revenue Service on request in connection with a tax evasion investigation. While other federal agencies cannot draw on FBI files without a showing of some need, and thus cannot go rummaging through the files on a "fishing expedition," there appears to be no guarantee that only information related to the specific needs of the requesting agency is handed over.

In his article on Army Intelligence, ${ }^{129}$ Christopher Pyle noted that agencies such as the Passport Office and the Civil Service Commission have access to the Army's data banks. ${ }^{130}$ The fears aroused by the knowledge that the Army is collecting information about one's political activities are compounded with the suspicion that the information will be available to the Passport Office when one applies to travel abroad or is in the hands of the Civil Service when one applies for a federal job. No rule appears to exist compelling the Passport Office or Civil Service to confront a person with the information it is acting upon and allow the individual a chance to rebut what is in the file. An individual thus may not get a job because of an uncontradicted shred of raw, unevaluated data culled from a dossier entry made years before.

\section{CONCLUSION}

It seems apparent that a great degree of discretion now rests with law enforceinent and national defense agencies who are counpiling dossiers. Also apparent is the lack of carefully devised standards to insure that the information compiled through preventative intelligence is not disserninated in an indiscriminate inanner. Until such time as a court is faced with a case where the use of dossiers is carefully and responsively thought out, and careful standards are devised, it would seem that a court could not properly uphold such systems in the face of a con-

128. See text accompanying notes 69-76 supra.

129. Pyle, supra note 16 , at 5 .

130. Id. at 4 . 
stitutional challenge. ${ }^{131}$

If dossiers must be used-a judgment which is open to serious doubt-a citizen should have a right to demand that pohicy-making bodies which have an interest in preserving constitutional rights as well as an interest in minimizing violence and civil disorder set standards for their use.

Merrick John Bobb

131. Even if such a system is devised by competent, politically responsive anthorities acting under an explicit grant of authority, it still may be the case that such systems violate first amendment freedoms in an impermissible inanner. A court may reasonably conclude that even a carefully devised system, on balance, does much more violence to protected freedoms than it provides security against civil disorder. 